\title{
BAHASA PROKEM DALAM BUKU PENGABDI NETIJEN KARYA GERALDY TAN: KAJIAN FONOLOGI DAN IMPLIKASINYA
}

\author{
Laeli Farkhati $^{* 1}$, Burhan Eko Purwanto ${ }^{2}$, Leli Triana ${ }^{3}$ \\ ${ }^{* 1,2,3}$ Prodi Pendidikan Bahasa dan Sastra Indonesia, Fakultas Keguruan dan Ilmu Pendidikan, \\ Universitas Pancasakti Tegal, Indonesia \\ E-mail: ${ }^{* 1}$ laelifarkhati1023@gmail.com, ${ }^{2}$ burhanekopurwanto58@ gmail.com, ${ }^{3}$ lelitriana99@ gmail.com
}

\begin{abstract}
ABSTRAK
Penelitian ini mengkaji tentang bahasa prokem dalam buku Pengabdi Netijen karya Geraldy Tan dan implikasinya terhadap pembelajaran bahasa Indonesia di SMA. Tujuan penelitian ini adalah untuk mendeskripsikan struktur fonologis bahasa prokem dalam buku Pengabdi Netijen karya Geraldy Tan dan mendeskripsikan implikasi hasil penelitian terhadap pembelajaran bahasa Indonesia di SMA. Pendekatan yang digunakan dalam penelitian ini adalah pendekatan deskriptif kualitatif. Sumber data dalam penelitian ini adalah tuturan penulis (Geraldy Tan) dalam buku Pengabdi Netijen. Teknik pengumpulan data yang digunakan adalah teknik lanjutan dari metode simak yaitu teknik catat. Dalam menganalisis data menggunakan metode padan ortografis dan metode padan translasional. Penyajian hasil analisis data menggunakan metode penyajian informal dan formal. Hasil penelitian menujukkan bahwa di dalam buku Pengabdi Netijen terdapat beberapa proses struktur fonologis bahasa prokem, meliputi: netralisasi (perubahan fonemis), zeroisasi (penghilangan fonem), metatesis (perubahan urutan fonem), monoftongisasi (perubahan dua fonem vokal menjadi satu fonem vokal), dan anaptiksis (penambahan fonem). Hasil penelitian ini dapat diimplikasikan dalam pembelajaran bahasa Indonesia di SMA kelas XII kompetensi dasar 4.4 menulis cerita sejarah pribadi dengan memperhatikan kebahasaan, terdapat pada materi teks cerita (novel) sejarah. Diharapkan hasil penelitian ini dapat membantu siswa dalam mengerjakan tugas menulis cerita sejarah pribadi.
\end{abstract}

Kata Kunci : Bahasa prokem, buku Pengabdi Netijen, implikasi pembelajaran.

\begin{abstract}
This study examines the prokem language in the book Pengabdi Netijen by Geraldy Tan and its implications for learning Indonesian in high school. The purpose of this study was to describe the phonological structure of the prokem language in the book Pengabdi Netijen by Geraldy Tan and to describe the implications of the research results on Indonesian language learning in high school. The approach used in this research is a qualitative descriptive approach. The source of data in this study is the author's speech (Geraldy Tan) in the book Pengabdi Netijen. The data collection technique used is an advanced technique from the listening method, namely the note-taking technique. In analyzing the data using the orthographic equivalent method and the translational equivalent method. Presentation of the results of data analysis using informal and formal presentation methods. The results show that in the book Pengabdi Netijen there are several processes of the phonological structure of prokem language, including: neutralization (phonemic changes), zeroization (deletion of phonemes), metathesis (change in phoneme order), monophthongization (change of two vowel phonemes into one vowel phoneme), and anapticsis (addition of phonemes). The results of this study can be implicated in learning Indonesian in high school class XII basic competence 4.4 writing personal history stories by paying attention to language, found in historical story texts (novels). It is hoped that the results of this study can help students in working on the task of writing personal history stories.
\end{abstract}

Keywords: Prokem language, Pengabdi Netijen book, learning implications.

\section{PENDAHULUAN}

Bahasa merupakan alat komunikasi yang dipakai manusia untuk mengungkapkan perasaan dan gagasan atau pikiran baik lisan maupun tulisan. Dengan menggunakan bahasa, komunikasi antar sesama manusia dapat berlangsung dengan baik [1]. Bahasa juga dapat berkembang seiring berjalannya waktu. Perkembangan bahasa Indonesia yang terjadi di zaman 
sekarang menambah keragaman bahasa yang ada di Indonesia. Ragam atau variasi bahasa masuk dalam bidang Sosiolinguistik. Sosiolinguistik adalah subdisiplin linguistik yang mempelajari bahasa dalam hubungan pemakainya di masyarakat. Dalam linguistik ini, antara lain, dibicarakan pemakai dan pemakaian bahasa, tempat pemakaian bahasa, tata tingkat bahasa, pelbagai akibat adanya kontak dua bahasa atau lebih, dan ragam serta waktu pemakaian ragam bahasa itu [2]. Variasi atau ragam bahasa adalah bentuk perubahan atau perbedaan dari berbagai manifestasi kebahasaan yang tidak bertentangan dengan kaidah kebahasaan [3]. Akan tetapi variasi bahasa seringkali bertentangan dengan kaidah kebahasaan. Salah satu variasi bahasa yang bertentangan dengan kaidah kebahasaan dan sering digunakan di zaman sekarang oleh kalangan anak muda baik lisan maupun tulisan adalah variasi bahasa prokem.

Bahasa prokem merupakan bahasa tidak resmi atau tidak baku, bahasa prokem erat kaitannya dengan anak muda atau remaja, karena pengguna bahasa prokem adalah kalangan anak muda. Anak muda pada dasarnya mudah mengikuti arus, suka menciptakan hal baru, dan apa yang sedang terkenal akan diikuti tidak terkecuali bahasa. Sebagian besar kata-kata yang termasuk bahasa gaul atau bahasa prokem yang digunakan oleh remaja merupakan hasil dari terjemahan, singkatan, maupun plesetan [4]. Maka dari itu, bahasa prokem sering berubah-ubah dan tidak mempunyai struktur yang pasti. Bahasa prokem yang digunakan di masyarakat dikenal dengan istilah slang [5]. Slang adalah ragam bahasa tak resmi yang digunakan oleh kaum remaja atau kelompok sosial tertentu untuk komunikasi intern sebagai upaya agar kelompok lain tidak mengerti [6]. Artinya dari penjelasan tersebut bahasa prokem adalah variasi bahasa yang bersifat khusus dan rahasia. Namun, dilihat dari penggunaan bahasa prokem sekarang sudah berbeda dengan penggunaan bahasa prokem yang dulu, bahasa prokem sekarang banyak digunakan oleh berbagai kelompok dan tidak bersifat rahasia lagi. Faktor yang mempengaruhinya adalah faktor teknologi, di zaman sekarang teknologi semakin canggih membuat masyarakat gemar menggunakan internet atau bermain sosial media, dari sosial media tersebut bahasa prokem dapat diketahui oleh siapa saja. Tidak terkecuali dapat digunakan dalam menulis sebuah buku.

Buku dengan judul Pengabdi Netijen karya Geraldy Tan merupakan buku autobiografi yang didalamnya terdapat bahasa prokem. Geraldy Tan merupakan seorang selebgram, youtubers, host, dan influencer kpop. Laki-laki milenial kelahiran 1997 mulai masuk ke dunia tulis menulis dan telah sukses melahirkan buku berjudul Pengabdi Netijen. Pengabdi Netijen adalah buku yang mengisahkan perjalanan hidup seorang Geraldy Tan, dari anak laki-laki yang sering dibully sampai menjadi sosok yang menginspirasi. Banyak pesan yang dapat diambil tapi, tidak menghilangkan sisi humoris dari seorang Geraldy Tan. Geraldy Tan memang dikenal memiliki humor yang tinggi. Sisi humoris dan jiwa muda seorang Geraldy Tan tersebut sampai pada pembuatan judul buku, yaitu terdapat kata pelesatan yang termasuk dalam bahasa prokem, kata tersebut adalah kata netijen.

Maraknya penggunaan bahasa prokem dalam berkomunikasi dapat berdampak buruk pada penggunaan bahasa Indonesia yang baik dan benar. Seperti yang sudah dijelaskan di atas bahasa prokem termasuk bahasa tidak baku, tidak sesuai dengan kaidah kebahasaan, dan tidak memiliki sebuah struktur bahasa yang pasti karena dapat berubah-ubah sesuai perkembangan zaman. Namun perubahan bahasa prokem tersebut memiliki banyak proses yang dapat dikaji menggunakan kajian fonologi. Dalam tinjauan sosiolinguistik juga dijelaskan bahwa bahasa prokem dapat dianalisis dari segi fonologis [7]. Secara etimologis kata fonologi berasal dari gabungan kata fon berarti 'bunyi, dan logi yang berarti 'ilmu' [8]. Kajian mendalam tentang bunyi-bunyi ujar ini diselidiki oleh cabang linguistik yang disebut fonologi [9]. Chaer mengklasifikasikan kajian fonologi menjadi dua bagian yaitu fonetik dan fonemik. Fonetik tidak memperhatikan bunyi atau fonem dapat membedakan makna, sedangkan fonemik memperhatikan bunyi atau fonem dapat membedakan makna [10].

Perubahan fonem merupakan salah satu proses pembentukan struktur fonologis bahasa. Muslich memiliki beberapa jenis perubahan fonem antara lain: asimilasi, disimilasi, modivikasi vokal, netralisasi, zeroisasi, metatesis, diftongisasi, monoftongisasi, dan anaptiksis [11]. Jenis- 
jenis tersebut walaupun termasuk klasifikasi perubahan fonem, akan tetapi di dalamya terdapat proses penambahan dan penghilangan fonem. Dari berbagai proses pembentukan struktur fonologis bahasa itulah, dapat disimpulkan bahwa dalam menganalisis struktur fonologis bahasa prokem pada buku Pengabdi Netijen karya Geraldy Tan, peneliti mengacu pada teori yang dikemukakan oleh Muslich. Alasannya yaitu penggalan-penggalan tuturan bahasa prokem dapat terbentuk karena mengalami lebih dari satu proses pembentukan struktur fonologis.

Berdasarkan uraian di atas peneliti tertarik untuk melakukan penelitian dengan judul "Bahasa Prokem dalam Buku Pengabdi Netijen Karya Geraldy Tan: Analisis Berdasarkan Kajian Fonologi dan Implikasinya terhadap Pembelajaran Bahasa Indonesia di SMA". Alasannya, karena peneliti tertarik dengan bahasa prokem yang di zaman sekarang semakin banyak digunakan. Kemudian, wujud data berupa penggalan-penggalan tuturan yang termasuk bahasa prokem juga banyak ditemukan dalam buku Pengabdi Netijen karya Geraldy Tan dan juga Geraldy Tan merupakan anak muda, yang hakikatnya bahasa prokem digunakan oleh kalangan anak muda. Selain itu, banyak proses pembentukan struktur fonologis bahasa prokem yang dapat diteliti menggunakan kajian fonologi. Peneliti berharap dapat menghasilkan sesuatu yang baru tentang penelitian kajian fonologi dan implikasinya terhadap pembelajaran bahasa Indonesia di SMA.

\section{METODOLOGI PENELITIAN}

Pendekatan yang dilakukan dalam penelitian ini adalah pendekatan deskriptif kualitatif. Hasil penelitian dari pendekatan tersebut tidak berupa angka melainkan berupa pendeskripsian kata-kata [12]. Tujuan penelitian ini adalah untuk mendapatkan gambaran yang lengkap, mendalam, dan akurat berupa kata-kata tertulis dari penelitian ini yang berjudul "Bahasa Prokem dalam Buku Pengabdi Netijen Karya Geraldy Tan: Kajian Berdasarkan Ancangan Fonologi dan Implikasinya terhadap Pembelajaran Bahasa Indonesia di SMA".

Sumber data dalam penelitian ini adalah tuturan Geraldy Tan dalam buku Pengabdi Netijen. Wujud data dalam penelitian ini adalah penggalan-penggalan tuturan Geraldy Tan yang termasuk bahasa prokem dalam buku Pengabdi Netijen. Setelah mengetahui wujud data, maka selanjutnya data yang berupa penggalan-penggalan tuturan Geraldy Tan yang termasuk bahasa prokem tersebut diidentifikasikan berdasarkan bentuk perubahan fonem menurut Muslich. Muslich membagi bentuk perubahan fonem ke dalam beberapa jenis antara lain: asimilasi, disimilasi, modivikasi vokal, netralisasi, zeroisasi, metatesis, diftongisasi, monoftongisasi, dan anaptiksis.

Teknik pengumpulan data yang digunakan adalah teknik lanjutan dari metode simak yaitu teknik catat. Jadi, dalam penelitian ini peneliti menyimak dengan membaca secara keseluruhan isi buku Pengabdi Netijen karya Geraldy Tan kemudian mencatat data yang ditemukan.

Analisis data dalam penelitian ini menggunakan metode padan ortografis dan metode padan translasional. Menggunakan metode padan ortografis karena penelitian ini fokus pada bagaimana bahasa prokem ditulis. Kemudian untuk meneliti proses fonologis diperlukan data fonologis yang memuat bentuk dasar dan bentuk turunan, dua bentuk tersebut untuk mendeteksi munculnya perubahan fonologis [13]. Oleh sebab itu peneliti menggunakan metode padan translasional karena bahasa yang diteliti adalah bahasa prokem yang alat penentunya adalah bahasa Indonesia. Peneliti artikan bahasa Indonesia sebagai bentuk dasar dan bahasa prokem sebagai bentuk turunan. Dalam metode padan ada teknik dasar dan teknik lanjutan [14]. Teknik yang digunakan dalam penelitian ini adalah teknik hubung banding menyamakan (HBS) dan teknik hubung banding membedakan (HBB). Jadi, data bahasa prokem yang sudah ditemukan kemudian dianalisis dengan cara dipadankan. Pemadanan dilakukan dengan memerhatikan perbedaan dan persamaan penulisan bahasa prokem dengan alat penentunya yaitu bahasa Indonesia.

BAHASA PROKEM DALAM BUKU PENGABDI NETIJEN KARYA GERALDY TAN: KAJIAN BERDASARKAN ANCANGAN FONOLOGI DAN MPLIKASINYATERHADAP PEMBELAJARAN BAHASA INDONESIA DI SMA (LAELI FARKHATI*1, BURHANEKO PURWANTO ${ }^{2}$, LELI TRIANA ${ }^{3}$ ) 
Teknik penyajian hasil analisis yang digunakan peneliti adalah teknik penyajian informal dan formal karena dalam penelitian initidak hanya menyajikan hasil analisis data berupa katakata, melainkan juga berupa tanda-tanda.Tanda-tanda yang digunakanadalah tanda garis miring (/ /) untuk menuliskan fonem dan tanda kurung sudut $(<>)$ untuk menuliskan suatu kata yang termasuk bahasa prokem.

\section{HASIL DAN PEMBAHASAN}

\section{Deskripsi Data Struktur Fonologis Bahasa Prokem dalam Buku Pengabdi Netijen Karya Geraldy Tan}

Data dalam penelitian ini berupa penggalan-penggalan tuturan penulis (Geraldy Tan) yang termasuk bahasa prokem. Hasil penelitian menunjukkan bahwa di dalam buku Pengabdi Netijen terdapat bahasa prokem. Bahasa prokem di dalam buku tersebut mengandung macammacam struktur fonologis yang berbeda. Perbedaan tersebut dikarenakan dalam proses terbentuknya bahasa prokem mengalami beberapa proses meliputi: proses netralisasi, zeroisasi, metatesis, monoftongisasi, dan proses anaptiksis.

Berdasarkan macam-macam proses tersebut, peneliti telah menemukan data sebanyak 57 data, di antaranya: 24 data netralisasi yaitu data yang mengalami proses perubahan fonem, 17 data zeroisasi yaitu data yang mengalami proses penghilangan fonem, 1 data metatesis yaitu data yang mengalami proses perubahan urutan fonem, 3 data monoftongisasi yaitu data yang mengalami proses perubahan dua fonem vokal menjadi satu fonem vokal, dan 12 data anaptiksis yaitu data yang mengalami proses penambahan fonem. Seluruh data diperoleh dari teknik simak dilanjutkan dengan teknik catat, dicatat mana data yang termasuk bahasa prokem lalu dianalisis dengan mencari padanan dalam bahasa Indonesia bakunya yaitu dengan cara membuka KBBI sebagai bukti bahwa ada perbedaan struktur fonologis antara data bahasa prokem dengan bahasa Indonesia yang baku.

Jadi, apabila ada perbedaan penulisan struktur fonologis maka data tersebut termasuk data penelitian ini. Penelitian ini menggunakan kajian fonologi, akan tetapi tidak meneliti bagaimana bunyi bahasa prokem, yang diteliti adalah penulisan struktur fonologisnya. Maka dari itu, pada penelitian ini menggunakan metode padan ortografis, karena yang dipadankan berupa bagaimana data yang diperoleh tersebut ditulis, kemudian karena meneliti penulisan struktur fonologisnya bukan meneliti bunyi maka pada penelitian ini dalam menganalisis menggunakan penulisan ortografis. Penulisan ortografis adalah penulisan yang ditulis menggunakan alfabet latin yang berjumlah 26 huruf dan sesuai PUEBI, sedangkan apabila membahas bunyi maka data ditulis menggunakan penulisan fonetik yaitu data ditulis persis seperti yang diucapkan.

\section{Analisis Data Struktur Fonologis Bahasa Prokem dalam Buku Pengabdi Netijen Karya Geraldy Tan}

Hasil penelitian ini adalah dalam buku Pengabdi Netijen karya Geraldy Tan ditemukan data struktur fonologis bahasa prokem meliputi: netralisasi, zeroisasi, metatesis, monoftongisasi, dan anaptiksis. Berikut analisis data struktur fonologis bahasa prokem.

1. Netralisasi

Netralisasi adalah perubahan fonemis akibat dari pengaruh lingkungan. Perubahan fonemis adalah perubahan fonem pada suatu kata. Berikut analisis data penelitiannya.

Konteks: Geraldy Tan mendapatkan komentar buruk dari cover lagu yang di upload.

Tuturan: Membaca komentar itu, gue langsung ke kamar mandi, nyalain shower, terus nangis kaya Manohara. Netijen emang tega. (Tan, 2018:61). 
Pada tuturan di atas, kata yang bercetak tebal dan miring yaitu kata <netijen> merupakan bentuk dari proses netralisasi atau perubahan fonem. Untuk mengetahui adanya perubahan fonem pada kata <netijen> yang termasuk bahasa prokem tersebut dibutuhkan padanan dalam bahasa Indonesia. Kata <netijen> berpadanan dengan kata <netizen> dalam bahasa Indonesai. Jadi, setelah mengetahui padanan tersebut dapat disimpulkan bahwa perubahan fonem yang terjadi pada kata <netizen> menjadi <netijen> yaitu perubahan fonem pada fonem /z/ menjadi fonem $/ \mathrm{j} /$. Makna kata <netizen> adalah warganet atau orang yang menggunakan internet khususnya dalam penggunaan sosial media.

2. Zeroisasi

Zeroisasi adalah penghilangan bunyi fonemis atau penghilangan fonem sebagai akibat dari upaya menghemat pengucapan. Dalam zeroisasi adamodel penyingkatan yang disebut kontraksi. Kontraksi merupakan hasil pemendekan suatu kata atau gabungan kata dengan cara menghilangkan fonem. Selain kontraksi zeroisasi juga diklasifikasikan menjadi tiga yaitu, aferesis (penghilangan fonem di awal kata), apokop (penghilangan fonem di akhir kata), dan sinkop (penghilangan fonem di tengah kata).

a. Kontraksi

Konteks: Geraldy Tan menceritakan ketekunannya membuat konten di Instagram.

Tuturan: Yap, pokoknya harus ada konten untuk gue unggah. Mau itu meme remake, meme gaje, apa ajalah. (Tan, 2018:13).

Pada tuturan di atas, yang bercetak tebal dan miring yaitu kata <gaje> mengalami proses zeroisasi atau penghilangan fonemis dengan model kontraksi. Kata <gaje> berasal dari dua kata yaitu <gak> dan <jelas>, dari dua kata tersebut dipendekan lalu disingkat menghasilkan satu kata yang baru. Kata <gaje> dimaksudkan untuk seseorang yang melakukan sesuatu tanpa kejelasan. Kata <gak> merupakan bahasa prokem yang berpadanan dengan kata <tidak> dalam bahasa Indonesia. Kata <gak> menjadi <tidak> mengalami dua proses perubahan struktur fonologis yaitu, yang pertama aferesis atau penghilangan di fonem awal kata yakni pada fonem /t/ dan /i/, yang kedua perubahan fonem atau netralisasi dari fonem /d/ menjadi /g/.

b. Aferesis (Penghilangan Fonem di Awal Kata)

Konteks: Geraldy Tan mengejek dengan candaan tentang hidup manusia yang tidak dapat diprediksi.

Tuturan: Mang enak! Ada orang yang dulunya pipisnya berdiri, pas udah gede pipisnya jongkong... EMMM Cucoookkk. (Tan, 2018:2).

Berdasarkan tuturan di atas, kata yang bercetak tebal dan miring yaitu kata <mang> merupakan kata yang termasuk bahasa prokem. Kata $<$ mang $>$ termasuk bentuk dari proses aferesis atau penghilangan fonem di awal kata. Untuk mengetahui suatu kata tergolong aferesis perlu diketahui padanan kata dalam bahasa Indonesianya. Kata <mang> berpadanan dengan kata <memang> dalam bahasa Indonesia. Jadi, dari kata <memang> menjadi <mang> menghilangkan dua fonem di awal kata yaitu fonem $/ \mathrm{m} /$ dan fonem $/ \mathrm{e} /$. Kata <memang> menurut KBBI V adalah sebenarnya atau benar-benar.

c. Apokop (Penghilangan Fonem di Akhir Kata)

Konteks: Geraldy Tan menceritakan dirinya mengikuti audisi X-faktor di RCTI.

Tuturan: Berbekal kenekatan yang $\boldsymbol{H Q Q}$, akhirnya gue nekat daftarin diri di official website, yang beberapa hari kemudian oleh panitia diberi nomor antrean audisi via email. (Tan, 2018:60). 
Kata yang bercetak tebal dan miring pada tuturan di atas yaitu, kata <HQQ> merupakan kata yang terbentuk dari beberapa proses perubahan struktur fonologis. Prosesnya yaitu netralisasi, apokop dan sinkop. Namun dalam data (38) hanya dijelaskan proses apokop. Kata $\langle\mathrm{HQQ}>$ merupakan kata yang termasuk bahasa prokem, kata $<\mathrm{HQQ}>$ berpadanan dengan kata <hakiki> dalam bahasa Indonesia. Jadi, dari penulisan kata $<$ hakiki> menjadi <HQQ> kaitannya dalam proses apokop atau penghilangan fonem di akhir kata, fonem yang hilang adalah fonem /i/. Kata <hakiki> menurut KBBI V memiliki makna benar; sebenarnya; sesungguhnya.

d. Sinkop (Penghilangan Fonem di Tengah Kata)

Konteks: Geraldy Tan menceritakan tentang orang-orang yang mempertanyakan orientasi seksualnya, karena masih saja sendiri atau jomblo.

Tuturan: Teman-teman... gue masih suka cewek kok. Suwer! Pokoknya no cowok, no ayam warna-warni, no dangdut. Okeee, thank you. "Trus, kalo normal kok masih jomblo kak?". (Tan, 2018:38).

Pada tuturan di atas, kata yang bercetak tebal dan miring yaitu kata <trus> terbentuk karena ada proses perubahan struktur fonologis yaitu proses sinkop atau penghilangan fonem di tengah kata. Kata <trus $>$ termasuk bahasa prokem yang dalam bahasa Indonesia berpadanan dengan kata <terus>. Jadi, dari penulisan kata <terus $>$ menjadi <trus $>$, fonem yang hilang di tengah kata adalah fonem /e/. Kata <terus > menurut KBBI V memiliki makna tetap berlanjut.

3. Metatesis (Perubahan Urutan Fonem)

Metatesis adalah perubahan urutan bunyi fonemis pada suatu kata.Berikut analisis data penelitiannya.

Konteks: Geraldy Tan menjawab dengan candaan pertanyaan dari fans yang tidak punya uang tetapi ingin membeli skin game.

Tuturan: Kismin lo ah Thesa. Makanya kerja dong, kalau gue baca dari aura lo. Lo cocok kerja jualan teh poci depan SD. (Tan, 2018:175).

Kata yang bercetak tebal dan miring pada tuturan di atas, yaitu kata <kismin $>$ merupakan kata yang termasuk bahasa prokem. Kata <kismin $>$ mengalami proses metatesis atau perubahan urutan fonem. Untuk mengetahui adanya perubahan urutan pada kata <kismin> perlu diketahui padanan kata dalam bahasa Indonesianya. Kata $<$ kismin $>$ berpadanan dengan kata <miskin> dalam bahasa Indonesia. Jadi, perubahan urutan fonem pada kata <miskin> menjadi <kismin > adalah /m/, /i/, /s/, /k/, /i/, dan /n/ diubah urutannya menjadi /k/, /i/, /s/, /m/, /i/, dan /n/. Kata <miskin> menurut KBBI V adalah kata yang memiliki makna tidak berharga; serba kekurangan (berpenghasilan sangat rendah).

4. Monoftongisasi

Adalah proses perubahanduabuah fonemvokal atau diftongmenjadi satu fonem vokal atau monoftong. Berikut analisis data penelitiannya.

Konteks: Geraldy Tan menceritakan saat dirinya dilahirkan.

Tuturan: 7 Mei 1997, ibu gue mengalami kontraksi pukul 05.00 subuh. Dengan segera, dia diangkut pake motor kaisar mobil menuju rumah sakit bersalin terdekat. (Tan, 2018:2).

Pada penggalan tuturan yang bercetak tebal dan miring di atas, kata <pake> merupakan bahasa prokem. Kata <pake> merupakan bentuk dari proses monoftongisisasi atau 
perubahanduafonemvocalmenjadi satu fonem vocal. Untuk membuktikan bahwa kata <pake> termasuk bentuk monoftongisasi, perlu diketahui padanan kata dalam bahasa Indonesianya. Kata <pake> berpadanan dengan kata <pakai> dalam bahasa Indonesia. Jadi, dari penulisan kata <pakai> menjadi <pake> dua fonem vokal yang berubah adalah fonem /ai/ menjadi satu fonem vokal yaitu fonem /e/. Kata <pakai> menurut KBBI V memiliki makna mengenakan.

\section{Anaptiksis}

Anaftiksis atau penambahan fonem adalah proses penambahan fonem vokal di antara dua konsonan dalam sebuah kata atau penambahan sebuah fonem konsonan pada sebuah kata tertentu. Ada tiga proses anaftiksis yaitu protesis (penambahan fonem di awal kata), epentesis (penambahan fonem di tengah kata), dan paragog (penambahan fonem di akhir kata).Berikut analisis data penelitiannya.

a. Protesis (Penambahan Fonem di Awal Kata)

Konteks: Geraldy Tan merasa senang sekali karena bisa sering bertemu dengan pujaan hatinya, Sri.

Tuturan: Dunia sempit sekali, tanpa disangka-sangka satu tahun ngggak ketemu, kami sekarang berada di SMP yang sama. Itu berarti gue bisa melihat wajah Sri bukan hanya seminggu sekali tapi seminggu 6 kali. WENAAAK (Tan, 2018:41).

Berdasarkan penggalan tuturan yang bercetak tebal dan miring di atas, kata <wenaaak> termasuk bahasa prokem. Kata <wenaaak> berpadanan dengan kata <enak> dalam bahasa Indonesia. Terbentuknya kata <enak> menjadi <wenaaak> karena adanya proses penambahan fonem di awal kata atau protesis dan penambahan fonem di tengah kata atau epentesis. Namun pada analisis di sini hanya dijelaskan proses protesis. Jadi, dari penulisan kata <enak> menjadi <wenaaak> mengalami dua penambahan fonem di awal kata yaitu fonem /w/ dan /e/. Fonem /w/ merupakan fonem konsonan semivokal, jadi penambahan fonem /w/ termasuk analisis protesis. Kata <enak> menurut KBBI V memilki makna nikmat atau menyenangkan.

b. Epentesis (Pembahan Fonem di Tengah Kata)

Konteks: Geraldy Tan mengejek dirinya sendiri karena ibunya mengetahui bahwa dia menyimpan video senonoh di ponselnya.

Tuturan: Perasaan gue nggak enak. Eh bener aja, ternyata pas gue intip, terlihat samarsamar nyokap lagi pegang hape gue. SYIIIPPP... fix banget ini mah, gue bakal dititipin di pantai asuhan. (Tan, 2018:75).

Kata yang bercetak tebal dan miring pada tuturan di atas, yaitu kata <syiiippp> merupakan kata yang termasuk bahasa prokem. Kata <syiiippp $>$ berpadanan dengan kata <sip> dalam bahasa Indonesia. Terbentuknya penulisan kata <sip> menjadi <syiiippp> karena adanya proses epentesis atau penambahan fonem di tengah kata dan paragog atau penambahan fonem di akhir kata. Namun pada analisis di sini hanya dijelaskan proses epentesis saja. Jadi, penambahan fonem di tengah kata pada penulisan kata <sip> menjadi <syiiippp> adalah penambahan fonem konsonan /y/ dan penambahan fonem deret vokal /ii/. Kata <sip> menurut KBBI V memilki makna mantap; elok; baik.

c. Paragog (Penambahan Fonem di Akhir Kata)

Konteks: Geraldy Tan menceritakan ketekunannya membuat konten di Instagram.

Tuturan: Yap, pokoknya harus ada konten untuk gue unggah. Mau itu meme remake, meme gaje, apa ajalah. (Tan, 2018:13). 
Pada penggalan tuturan yang bercetak tebal dan miring di atas, kata $\langle y a p\rangle$ merupakan bahasa prokem yang dalam bahasa Indonesia berpadanan dengan kata $\langle$ ya $\rangle$. Kata $\langle$ ya $\rangle$ menjadi <yap> mengalami beberapa proses penambahan fonem di akhir kata atau paragog. Jadi, penambahan fonem di akhir kata pada penulisan kata <ya $>$ menjadi <yap > adalah penambahan fonem /p/. Kata <ya> menurut KBBI V merupakan kata untuk menyatakan setuju (membenarkan dan sebagainya).

\section{Pembahasan Hasil Analisis Data}

Hasil analisis menunjukkan bahwa telah ditemukan data bahasa prokem dalam buku Pengabdi Netijen karya Geraldy Tan sebanyak 57 data, di antaranya: 24 data netralisasi yaitu bentuk data yang mengalami proses perubahan fonem, 17 data zeroisasi yaitu bentuk data yang mengalami proses penghilangan fonem, 1 data metatesis yaitu bentuk data yang mengalami proses perubahan urutan fonem, 3 data monoftongisasi yaitu bentuk data yang mengalami proses perubahan dua fonem vokal menjadi satu fonem vokal, dan 12 data anaptiksis yaitu bentuk data yang mengalami proses penambahan fonem.

Berdasarkan perolehan data di atas, diketahui bahwa struktur fonologis bahasa prokem dalam bentuk netralisasi paling banyak ditemukan dan bentuk metatesis paling sedikit ditemukan. Faktor lingkungan sangat memengaruhi penggunaan bahasa prokem di kalangan anak muda. Lingkungan anak muda seringkali menggunakan bahasa prokem dengan tujuan untuk memberikan kesan akrab, santai, dan untuk mengikuti bahasa prokem yang sedang populer atau sedang trend. Ketiga tujuan tersebut merupakan faktor-faktor yang memengaruhi pemerolehan hasil mengapa dalam penelitian ini bentuk netralisasai paling banyak ditemukan yaitu 24 data, kemudian zeroisasi 17 data, anaptiksis 12 data, monoftongisasi 3 data, dan metatesis hanya ditemukan 1 data.

Untuk lebih jelasnya mengenai bentuk apa saja yang terpengaruhi oleh tiga faktor terebut atau bahkan ada faktor lainnya. Berikut penjelasan mengenai faktor-faktor yang memengaruhi pemerolehan masing-masing bentuk struktur fonologis bahasa prokem dalam buku Pengabdi Netijen karya Geraldy Tan.

1. Netralisasi merupakan bentuk struktur fonologis bahasa prokem yang paling banyak ditemukan atau dominan yaitu sebanyak 24 data. Faktor yang memengaruhinya adalah kalangan anak muda menyukai bahasa yang santai. Penggunaan kata baku yang terkesan formal diubah satu atau dua fonem pada setiap kata untuk menghilangkan unsur formal dalam berkomunikasi di kalangan anak muda. Kemudian faktor lainnya yaitu faktor kepopuleran penggunaan bahasa prokem, bentuk netralisasi kepopulerannya tidak menurun karena tidak cepat terjadi perubahan, sehingga kalangan anak muda turun temurun menggunakan bahasa prokem yang sama. Jadi, tidak heran Geraldy Tan benyak menggunakan bahasa prokem bentuk netralisasi.

2. Zeroisasi, metatesis dan anaptiksis. Peneliti menggabungkan tiga bentuk struktur fonologis tersebut, karena pemerolehan data ketiga bentuk tersebut tidak lebih banyak dari bentuk netralisi dan memiliki faktor yang sama. Faktor yang sama mengenai mengapa pemerolehan ketiga bentuk tersebut tidak lebih banyak dari bentuk netralisasi yaitu, zeroisasi ditemukan 17 data, anaptiksis 12 data, dan metatesis hanya ditemukan 1 data. Faktornya adalah faktor kepopuleran penggunaan bahasa prokem. Seringkali ketiga bentuk tersebut digunakan hanya untuk mengikuti trend, karena ketiga struktur fonologis bentuk bahasa prokem tersebut cepat mengalami perubahan seiring berjalannya waktu. Jadi, Geraldy Tan menggunakan ketiga bentuk tersebut hanya untuk mengikuti trend penggunaan bahasa prokem pada masa pembuatan atau penulisan buku saja. Apa yang sedang populer, Geraldy Tan gunakan dalam penulisan bukunya.

3. Monoftongisasi, dalam buku Pengabdi Netijen karya Geraldy Tan bentuk monoftongisasi hanya ditemukan 3 data. Walaupun data dalam bentuk monoftongisasi juga ditemukan sedikit, faktor yang memengaruhinya bukan dari faktor kepopuleran penggunaan bahasa prokem, 
melainkan ada faktor lain. Bentuk monoftongisasi sama halnya dengan bentuk netralisasi yaitu terus menerus digunakan karena tidak cepat terjadi perubahan. Maka dari itu, faktor yang memengaruhi mengapa pemerolehan data bentuk monoftongisasi ditemukan sedikit hanya 3 data, faktornya adalah kata yang memiliki dua fonem vokal atau rangkap (diftong), tidak sebanyak kata yang urutan fonemnya vokal lalu konsonan atau sebaliknya. Kemudian faktor lainnya yaitu Geraldy Tan maupun editor bukunya dalam menggunaan kata yang termasuk diftong sudah ditulis dengan benar tanpa dimonoftongisasi. Dua faktor itulah yang membuat data bentuk monoftongisasi hanya ditemukan 3 data.

\section{Implikasi Hasil Penelitian dalam Pembelajaran Bahasa Indonesia di SMA}

Pembelajaran Bahasa Indonesia adalah pembelajaran yang bertujuan agar siswa mengetahui dan menguasai empat keterampilan bahasa yaitu, mendengar, berbicara, membaca, dan menulis. Keempat keterampilan tersebut pastinya diajarkan sesuai dengan kaidah atau aturan bahasa Indonesia. Kaidah bahasa Indonesia meliputi kaidah tata bahasa, kaidah ejaan dan kaidah pembentukan istilah. Kaidah tata bahasa dan pembentukan istilah berkaitan dengan bahasa lisan dan tulisan atau berkaitan dengan keterampilan berbicara, membaca, dan menulis. Sedangkan kaidah ejaan hanya berkaitan dengan penggunaan bahasa Indonesia tulis atau hanya keterampilan menulis dan untuk keterampilan mendengar seringkali digunakan untuk menyimak sebuah diskusi yang nantinya siswa dapat memberikan tanggapan dengan baik.

Tujuan pembelajaran bahasa Indonesia yang berkaitan dengan penelitian ini adalah tujuan menguasai keterampilan menulis dengan memperhatikan kaidah ejaan. Kaidah ejaan dibagi menjadi dua yaitu, kaidah dalam penggunaan kata dan kaidah dalam penggunaan tanda baca, yang berkaitan dengan penelitian ini adalah kaidah dalam penggunaan kata. Penggunaan kata yang dimaksud adalah penggunaan kata yang termasuk bahasa prokem pada buku Pengabdi Netijen karya Geraldy Tan.

Berdasarkan penjelasan di atas, hasil penelitian ini dapat diimplikasi dalam pembelajaran bahasa Indonesia yaitu pada Kompetensi Dasar (KD) 4.4 menulis cerita sejarah pribadi dengan memperhatikan kebahasaan, KD tersebut terdapat dalam materi teks cerita (novel) sejarah, kelas XII semester ganjil. Pada KD 4.4 menulis cerita sejarah pribadi dengan memperhatikan kebahasaan, pastinya siswa harus menggunakan bahasa Indonesia yang baku. Walaupun tugas siswa adalah menulis cerita sejarah pribadi, layaknya menulis diari yang sering kali bahasa yang digunakan adalah bahasa tidak baku atau informal dan siswa juga sering menambahkan bahasa yang sedang populer digunakan atau nama lainnya adalah bahasa prokem. Namun, harus diingat penggunaan bahasa formal dan informal ditentukan oleh waktu dan situasi digunakannya bahasa tersebut [15]. Tugas menulis tersebut nantinya akan dibaca oleh guru dan aspek kebahasaan akan dinilai. Dari situasinya, maka penggunaan bahasa yang digunakan siswa haruslah bahasa yang baku atau formal.

Dari penelitian inilah siswa dapat mengetahui penggunaan bahasa Indonesia yang baku, karena dalam penelitian ini dijelaskan padanan bahasa prokem dengan bahasa Indonesia bakunya. Misal, kata <kismin> merupakan bahasa prokem berpadanan dengan kata <miskin> dalam bahasa Indonesia. Pengetahuan itulah yang nantinya digunakan siswa dalam mengerjakan tugas menulis cerita sejarah pribadi, supaya siswa mendapatkan nilai yang maksimal karena memperhatikan kaidah bahasa Indonesia dengan baik. Kaitannya dengan hasil penelitian menganalisis struktur fonologis bahasa prokem dalam buku Pengabdi Netijen karya Geraldy Tan adalah siswa dapat menambah wawasan kebahasaan mengenai asal mula atau proses yang terjadi bagaimana kata yang termasuk bahasa prokem itu terbentuk.

Jenis buku yang diteliti dalam penelitian ini juga memiliki kesamaan dengan KD 4.4 yaitu menulis cerita sejarah pribadi dengan memerhatikan kebahasaan. Buku Pengabdi Netijen adalah buku autobiografi yang di dalamnya menceritakan sejarah pribadi penulis yaitu Geraldy Tan yang ditulisnya sendiri, jadi tugas siswa dan buku ini adalah sama-sama cerita sejarah pribadi. Isi buku Pengabdi Netijen juga tidak jauh dari kehidupan sekolah dan meraih cita-cita, jadi untuk kalangan 
siswa SMA sangat cocok membaca buku Pengabdi Netijen karya Geraldy Tan. Diharapkan penelitian ini dapat menjadi bahan ajar guru atau pendidik dalam kegiatan pembelajaran. Berikut langkah-langkah pembelajaran bahasa Indonesia KD 4.4 menulis cerita sejarah pribadi dengan memerhatikan kebahasaan.

1. Kegiatan Pendahuluan ( 1 x 10 menit)

a. Guru membuka pelajaran dengan mengucapkan salam dan peserta didik menjawab salam.

b. Guru dan peserta didik melakukan doa bersama.

c. Guru mengecek kehadiran peserta didik.

d. Guru melakukan apersepsi mengenai materi sebelumnya.

e. Guru menyampaikan tujuan pembelajaran yang ingin dicapai.

2. Kegiatan Inti (1 x 40 menit)

a. Peserta didik membaca materi tentang menyusun teks cerita sejarah.

b. Guru menjelaskan materi tentang menyusun teks cerita (novel) sejarah.

c. Guru melakukan sesi tanya jawab.

d. Peserta didik diberikan contoh teks cerita sejarah pribadi oleh guru yang berjudul Balikin Gue Ke Sekolah Lagi yang ada di dalam buku Pengabdi Netijen karya Geraldy Tan.

e. Guru melakukan sesi tanya jawab.

f. Peserta didik bersama guru mengomentari dan merevisi contoh teks tersebut sudah sesuai dengan kebahasaan cerita sejarah atau belum.

3. Kegiatan Penutup (1 x 10 menit)

a. Peserta didik dan guru membuat kesimpulan dari materi sudah yang dipelajari.

b. Guru memberikan tugas menyusun teks cerita sejarah pribadi.

c. Guru menginformasikan rencana kegiatan berikutnya yaitu siswa mengumpulkan tugas yang telah ditulis dan dipresentasikan.

d. Guru memberikan motivasi belajar.

Guru menutup pelajaran dengan mengucap salam.

\section{SIMPULAN}

Berdasarkan hasil penelitian yang sudah dilakukan, dapat disimpulkan bahwa terdapat struktur fonologis bahasa prokem pada buku Pengabdi Netijen karya Geraldy Tan dalam bentuk netralisasi (perubahan fonemis) sebanyak 24 data, zeroisasi (penghilangan fonem) sebanyak 17 data, metatesis (perubahan urutan fonem) sebanyak 1 data, monoftongisasi (perubahan dua fonem vokal menjadi satu fonem vokal) sebanyak 3 data, dan anaptiksis (penambahan fonem) sebanyak 12 data. Total data yang ditemukan berjumlah 57 data. Kemudia hasil penelitian ini dapat diimplikasikan pada pembelajaran Bahasa Indonesia di SMA yaitu kelas XII semester ganjil pada materi teks cerita (novel) sejarah dalam kompetensi dasar 4.4 menulis cerita sejarah pribadi dengan memerhatikan kebahasaan. Implikasinya adalah dari penelitian ini siswa dapat menulis cerita sejarah pribadi dengan kaidah bahasa Indonesia yang baik dan benar yaitu dalam penggunaan bahasa Indonesia yang baku. Kaitannya dengan struktur fonologis pada penelitian ini adalah siswa dapat menambah wawasan kebahasaan mengenai asal mula atau proses terbentuknya kata yang termasuk bahasa prokem.

\section{REFERENCES}

[1] D. K. dkk Anggaraini, "Bahasa Gaul Pada Status Facebook Siswa SMK Muhammadiyah Kramat Kabupaten Tegal," J. Skripta, vol. 6, no. September, pp. 54-63, 2020.

[2] Chaer, Abdul. 2007. Linguistik Umum. Jakarta: Rineka Cipta.

[3] Ohoiwutun, Paul. 2007. Sosiolinguistik: Memahami Bahasa dalam Masyarakat

BAHASA PROKEM DALAM BUKU PENGABDI NETIJEN KARYA GERALDY TAN: KAJIAN BERDASARKAN ANCANGAN FONOLOGI DAN MPLIKASINYATERHADAP PEMBELAJARAN BAHASA INDONESIA DI SMA (LAELI FARKHATI*1, BURHANEKO PURWANTO ${ }^{2}$, LELI TRIANA ${ }^{3}$ ) 
dan Kebudayaan. Jakarta: Kesaint Blanc.

[4] D. S. Istiqomah, D. S. Istiqomah, and V. Nugraha, "Analisis penggunaan bahasa prokem dalam media sosial," vol. 1, no. September, pp. 665-674, 2018.

[5] R. Amaliah and F. Putera, "ALFABETA: Jurnal Bahasa , Sastra , dan Pembelajarannya Karakteristik Bahasa Prokem Pada Masyarakat Dwibahasawan Madura-Indonesia," vol. X, pp. 27-35, 2021.

[6] Kridalaksana, Harimurti. 1993. Kamus Linguistik. Jakarta: PT Gramedia.

[7] A. Hasibuan, U. Muslim, and N. A. Medan, "PEMAKAIAN BAHASA PROKEM OLEH REMAJA KECAMATAN," vol. 1, no. 2, pp. 72-79.

[8] Chaer, Abdul. 2019. Fonologi Bahasa Indonesia. Jakarta: Rineka Cipta.

[9] Muslich, Masnur. 2008. Fonologi Bahasa Indonesia: Tinjauan Deskriptif Sistem Bunyi Bahasa Indonesia. Jakarta: PT Bumi Aksara.

[10] W. Oktavia, "Perubahan Fonologis Bahasa Gaul dalam Percakapan Whatsapp Kelompok Siswa Kelas 9 MTs Muhammadiyah 05 Kemusu," vol. 3, no. 1, 2020, doi: 10.29240/estetik.v3i1.1464.

[11] Muslich, Masnur. 2008. Fonologi Bahasa Indonesia: Tinjauan Deskriptif Sistem Bunyi Bahasa Indonesia. Jakarta: PT Bumi Aksara.

[12] W. Oktavia, "Perubahan Fonologis Bahasa Gaul dalam Percakapan Whatsapp Kelompok Siswa Kelas 9 MTs Muhammadiyah 05 Kemusu," vol. 3, no. 1, 2020, doi: 10.29240/estetik.v3i1.1464.

[13] S. Nafisah, "Proses Fonologis Dan Pengkaidahannya," Deiksis, vol. 09, no. 01, pp. 70-78, 2017, [Online]. Available: https://journal.lppmunindra.ac.id/index.php/Deiksis/article/download/940/1058.

[14] Sudaryanto. 1993. Metode dan Aneka Teknik Analisis Bahasa (Pengantar Penelitian Wahana Kebudayaan secara Linguistik). Yogyakarta: Duta Wacana University Press.

[15] K. K. Kudus, “(Printed) ISSN 2598-3202 (Online) ISSN 2599-316X,” vol. 3202, 2002. 